\title{
IMPLEMENTASI PENDIDIKAN KARAKTER PADA MADRASAH IBTIDAIYAH
}

\section{Dian}

Universitas Islam Negeri Sunan Gunung Djati Bandung

JI. A.H. Nasution No. 105, Cibiru Bandung, Jawa Barat, 40614

Email: diankutunggu@gmail.com

\section{Wili Ramdan}

Universitas Islam Negeri Sunan Gunung Djati Bandung

Jl. A.H. Nasution No. 105, Cibiru Bandung, Jawa Barat, 40614

Email:wiliramdan03@gmail.com

\begin{abstract}
ABSTRAK
Hasil penelitian ini dapat disimpulkan bahwa latar alamiah Madrasah Ibtidaiyah Miftahul Huda Mandalajati didirikan atas dasar semangat pengajian warga Mandalajati yang menginginkan masyarakatnya agar selalu mendekatkan dirinya kepada Allah Swt dan Rosulnya Nabi Muhammad Saw. Perencanaan pendidikan karakter dilakukan oleh tim khusus kurikulum Yayasan Fathul Huda yang dibuat dalam sebuah buku khusus pendidikan karakter. Pengorganisasian pendidikan karakter di Madrasah Ibtidiayah Miftahul Huda dilakukan dengan struktur organisasi yang jelas, tugas dan tanggung jawab, serta deskripsi pekerjaan yang sudah dibuat seminggu sebelum tahun pembelajaran dimulai. Pengarahan pendidikan karakter dilakukan dengan adanya buku panduan pendidikan karakter, mengundang Ustadz untuk pengajian, penjelasan dan penguatan dari Kapala Madrasah. Pengendalian pendidikan karakter dilakukan dengan cara monitoring ke setiap kelas 4 kali setahun dan evaluasi setiap 3 bulan sekali untuk mengukur keberhasilan pendidikan karakter. Faktor penunjang pendidikan karakter adalah SDM, sarana dan prasarana, penguatan kompetisi tahfidz dan pengembangan e-learning sedangkan faktor penghambat pendidikan karakter adalah sarana dan prasarana, kematangan konsep, standar mutu pendidikan, cara pandang masyarakat terhadap pendidikan. Keberhasilan pendidikan karakter dapat diketahui dari kriteria keberhasilan, efektif dan efisian manajemen pendidikan karakter.
\end{abstract}

Kata Kunci : Implementasi, Pendidikan Karakter, Madrasah Ibtidaiyah.

\section{ABSTRACT}

The results of this research can be concluded that the natural background Madrasah Ibtidaiyah Miftahul Huda Mandalajati was founded on the spirit of recitation of Mandalajati citizens who want the community to always get closer to Allah swt and Prophet Muhammad Saw. Character education planning is done by a special team of curriculum foundation Fathul Huda made in a special book character education. The characters education organization in Madrasah 
Ibtidaiyah Miftahul Huda is done with clear organizational structure, duties, and responsibilities, as well as job descriptions that have been made a week before the learning year begins. Character education direction is done with character education guidebook, inviting master of Islam for the recitation of Qur'an, explanation and strengthening from the head of the madrasah. Character education control by monitoring to each class four times a year and evaluate once every three months to measure the success of character education. Character supporting factors are human resources, facilities, and infrastructure, strengthening tahfidz competition and e-learning development while inhibiting character education are facilities and infrastructure, concept maturity, the standard of education quality, the way of the view of society to education. The success of character education can be known from the criteria of success, effective and efficient management of character education.

Kata Kunci : Implementasi, Pendidikan Karakter, Madrasah Ibtidaiyah.

\section{PENDAHULUAN}

Menurut Undang-undang Sistem Pendidikan Nasional Nomor 20 Tahun 2003, Pendidikan Nasional berfungsi mengembangkan kemampuan dan membentuk watak serta peradaban bangsa yang bermartabat dalam rangka mencerdaskan kehidupan bangsa, bertujuan untuk berkembangnya potensi peserta didik agar menjadi manusia yang beriman dan bertakwa kepada Tuhan Yang Maha Esa, berakhlak mulia, sehat, berilmu, cakap, kreatif, mandiri, dan menjadi warga negara yang demokratis serta bertanggung jawab.

Para pendukung teori Darwin mengatakan bahwa kehidupan biologis yang muncul saat ini merupakan hasil dari produk evolusi. Pandangan tersebut mengantarkan masyarakat untuk melihat hal lain yang berbeda, termasuk sikap moral yang lebih bersifat berkembang daripada kaku atau bersifat benar atau salah (T. Lickona, 2013, h. 9).

Pendidikan karakter merupakan upaya untuk membantu perkembangan jiwa anak-anak baik lahir maupun batin, dari sifat kodratnya menuju ke arah peradaban yang manusiawi dan lebih baik. Sebagai contoh dapat dikemukakan misalnya: anjuran atau suruhan terhadap anak-anak untuk duduk dengan baik, tidak berteriak-teriak agar tidak mengganggu orang lain, bersih badan, rapi pakaian, hormat terhadap orang tua, menyayangi yang muda, menghormati yang tua, menolong teman dan seterusnya merupakan proses pendidikan karakter (E. Mulyasa, 2013, h. 1).

Pendidikan karakter di Indonesia dirasakan amat perlu pengembangannya bila mengingat makin meningkatnya tawuran antar-pelajar, serta bentuk-bentuk kenakalan remaja lainnya terutama di kota-kota besar, pemerasan/kekerasan (bullying), kecenderungan dominasi senior terhadap junior, fenomena suporter bonek, penggunaan narkoba, dan lain-lain. Bahkan yang paling memprihatinkan, keinginan untuk membangun sifat jujur pada anak-anak melalui kantin kejujuran di sejumlah sekolah, banyak yang gagal, banyak usaha kantin kejujuran yang bangkrut karena belum bangkitnya sikap jujur pada anak-anak (Muchlas dan Hariyanto, 2012, h. 2).

Madrasah Ibtidaiyah Miftahul Huda (MIMHa) ini sudah melaksanakan pendidikan karakter sejak tahun 2004 dengan program unggulannya yaitu 
cerdas berkarakter tauhid. Dengan adanya program ini diharapkan siswasiswinya memiliki pengalaman yang mencirikan seorang muslim sejati yang mengesakan Tuhannya dengan cara memiliki hubungan 3 dimensi yaitu hubungan dengan Allah, hubungan dengan manusia dan hubungannya dengan alam. Pendidikan karakter yang dikembangkan di MIMHa adalah 5 nilai dasar karakter tauhid: Ikhlas, Adil, Jujur, Tanggung jawab, dan Santun. Cerdas karakter tauhid adalah cerdas berbasis karakter yang bersumber kepada Alquran dan Al-Hadist, cerdas dalam matematika tetapi tetap tidak sombong. Madrasah Diniyah sebagai basis nilai dengan karakter tauhid, materi Madrasah Diniyah yang awal sebagai penguatan pendidikan karakter tauhid. Pemecahan masalah dalam setiap pembelajaran, mulai dari buku, murid, guru, dan lain-lain. Pelaksanaan pendidikan karakter tauhid ini dilakukan dengan jadwal kegiatan sehari-hari pembiasan di kelas, pembiasaan shalat duha, penguatan karakter kepada siswa-siswi, pembiasaan sebelum ke materi, SDSQ (sekolah dengan sentuhan Al-quran) mulai dari tahsin dan tahfidz, hal-hal lainnya, setelah itu pembelajaran inti dilaksanakan.

\section{KAJIAN TEORI}

Menurut Agus Wibowo manajemen pendidikan karakter sebagai proses, memiliki fungsi-fungsi sebagaimana manajemen dan manajemen pendidikan pada umumnya. Adapun fungsi-fungsi manajemen pendidikan karakter adalah membuat perencanaan dan keputusan (planning); mengorganisasikan sumber daya yang dimiliki (organizing); melakukan pengarahan agar sumber daya yang dimiliki, bisa mencapai tujuan secara efektif dan efisien; dan melaksanakan pengendalian (controlling). Fungsi-fungsi manajemen pendidikan tersebut, dilaksanakan secara integratif, sinergis, dan berkelanjutan. Muara atau tujuan dari manajemen pendidikan karakter di sekolah, adalah tercapainya tujuan pendidikan karakter di sekolah yang efektif dan efisien. Melalui ketercapaian tujuan pendidikan karakter di sekolah, diharapkan terlahir generasi muda masa depan, khususnya peserta didik yang tidak saja cerdas secara psikomotorik, tetapi juga memiliki keluhuran karakter (Agus Wibowo, 2013, h. 138).

Perencanaan merupakan aspek penting dalam manajemen pendidikan karakter di sekolah. Perencanaan pendidikan karakter di sekolah memiliki dua makna penting, yaitu perencanaan program dan kegiatan penanaman karakter oleh sekolah, serta penanaman nilai-nilai karakter kepada para pembuat rencana itu sendiri. Dengan demikian, penanaman nilai-nilai tidak hanya kepada peserta didik, tetapi juga kepada para pembuat perencanaan. Inilah yang membedakan antara perencanaan pendidikan karakter, dengan perencanaan-perencanaan lainnya dalam korpus manajemen. Perencanaan pendidikan karakter di sekolah harus berangkat dari visi sekolah yang akan diwujudkan pada masa yang akan datang, misi yang akan dikembangkan, nilai yang akan dimiliki, tujuan yang akan dicapai dalam waktu tertentu, serta jenis tindakan yang akan dilaksanakan dalam rangka mencapai tujuan pendidikan karakter. Dengan demikian, diharapkan perencanaan pendidikan karakter akan efektif dan efisien ketika pada saatnya diimplementasikan (Agus Wibowo, 2013, h. 139-143).

Setelah perencanaan pendidikan karakter sudah dilakukan dengan matang, maka langkah selanjutnya adalah melakukan pengorganisasian. 
Pengorganisasian merupakan alat atau sarana yang digunakan untuk meraih apa yang telah direncanakan. Pengorganisasian merupakan fungsi manajemen yang mencakup kegiatan-kegiatan sebagai berikut: (a) Adanya pembagian kerja (job description) yang jelas. (b) Pembagian aktivitas menurut level kekuasaan dan tanggung jawab. (c) Pembagian dan pengelompokan tugas menurut mekanisme koordinasi kegiatan individu dan kelompok. (d) Pengaturan hubungan kerja antar anggota organisasi (Agus Wibowo, 2013, h. 148-149).

Pengarahan adalah usaha memberikan bimbingan, saran, perintah, atau instruksi kepada bawahan dalam melaksanakan tugas masing-masing, agar tugas dapat dilaksanakan dengan baik dan benar-benar tertuju pada tujuan yang telah ditetapkan. Pengarahan berfungsi bukan saja agar pegawai melaksanakan atau tidak melaksanakan suatu kegiatan, tetapi juga berfungsi mengkoordinasikan kegiatan agar efektif tertuju kepada realisasi tujuan yang ditetapkan. Adapun fungsi pengarahan dalam pendidikan karakter yang harus dilakukan sendiri oleh kepala sekolah, diantaranya: (a) Mengadakan orientasi sebelum guru dan memulai melaksanakan tugas dalam hal ini mengimplementasikan pendidikan karakter. (b) Memberikan petunjuk dan penjelasan mengenai implementasi pendidikan karakter yang akan dilakukan dengan secara lisan maupun tertulis (menjelaskan bagaimana grand design, model dan bentuk pembelajaran, model SP dan RP. (c) Memberikan kesempatan guru dan staf untuk berpartisipasi berupa pemberian sumbangan pikiran demi tercapainya tujuan implementasi pendidikan karakter di sekolah. (d) Mengikutsertakan guru, staf dan segenap warga sekolah dalam pembuatan perencanaan manajemen pendidikan karakter di sekolah, dan (e) Memberikan nasihat apabila guru atau staf mengalami kesulitan dalam melaksanakan tugas implementasi pendidikan karakter di sekolah (Agus Wibowo, 2013, h. 151-153).

Pengendalian dalam pendidikan karakter berfungsi untuk melihat apakah program-program pendidikan karakter yang telah disepakati dan didistribusikan kepada guru dan staf telah dilaksanakan sesuai dengan standar oprasional pelaksanaan atau belum. Pengendalian yang dilakukan kepala sekolah bukan bertujuan untuk mencari-cari kesalahan guru dan staf, tetapi untuk memperbaiki proses dalam rangka perbaikan hasil (Agus Wibowo, 2013, h. 172).

Menurut Akdon lingkungan internal meliputi kekuatan dan kelemahan organisasi. Kekuatan (Strength) adalah situasi dan kemampuan internal yang bersifat positif yang memungkinkan organisasi memenuhi keuntungan strategik dalam mencapai visi dan misi. Sedangkan kelemahan (Weakness) adalah situasi dan faktor-faktor luar organisasi yang bersifat negatif dan menghambat organisasi mencapai atau melampaui pencapaian visi dan misi (Badrudin, 2013: 102). Lingkungan eksternal meliputi peluang dan tantangan organisasi. Peluang (Opportunity) adalah situasi dan faktor-faktor luar organisasi yang bersifat positif dan membantu organisasi mencapai atau mampu melampaui pencapaian visi dan misi. Sedangkan tantangan (Threats) adalah faktor-faktor luar organisasi yang bersifat negatif dan dapat mengakibatkan organisasi gagal dalam mencapai visi dan misi.

\section{METODOLOGI}

Pendekatan yang dilakukan dalam penelitian ini adalah pendekatan kualitatif, yaitu suatu proses penelitian dan pemahaman yang berdasarkan 
pada metodologi yang menyelidiki suatu fenomena sosial dan masalah manusia. Penelitian ini tidak dimaksudkan untuk menguji hipotesis tetapi hanya menggambarkan secara objektif dan apa adanya mengenai manajemen pendidikan karakter di Madrasah Ibtidaiyah Miftahul Huda Kecamatan Mandalajati Kota Bandung. Yaitu yang berkaitan dengan: Latar alamiah Madrasah Ibtidaiyah Miftahul Huda Kelurahan Karang Pamulang Kecamatan Mandalajati Kota Bandung. Data tentang manajemen pendidikan karakter di Madrasah Ibtidaiyah Miftahul Huda Kelurahan Karang Pamulang Kecamatan Mandalajati Kota Bandung. Data tentang faktor penunjang dan faktor penghambat pendidikan karakter di Madrasah Ibtidaiyah Miftahul Huda Kelurahan Karang Pamulang Kecamatan Mandalajati Kota Bandung. Data tentang hasil dari manajemen pendidikan karakter di Madrasah Ibtidaiyah Miftahul Huda Kelurahan Karang Pamulang Kecamatan Mandalajati Kota Bandung. Data kuantitatif sebagai data penunjang manajemen pendidikan karakter di Madrasah Ibtidaiyah Miftahul Huda Kelurahan Karang Pamulang Kecamatan Mandalajati Kota Bandung.

Jenis data dalam penelitian kualitatif berupa deskriptif kata-kata tertulis atau lisan yang diperoleh dari narasumber yang berkompeten. Data tersebut dikumpulkan menggunakan teknik wawancara dengan mengajukan daftar pertanyaan secara rinci. Selain itu, juga dibutuhkan data kuantitatif tambahan sebagai data pelengkap, seperti jumlah siswa, jumlah tenaga pendidik, dan jumlah sarana prasarana, dan data lain yang sesuai kajian yang akan di teliti. Sampel penelitian yang terlibat dalam penelitian ini meliputi kepala Madrasah yang sekaligus sebagai penanggung jawab pendidikan karakter di MI Miftahul Huda.

Teknik pengumpulan data untuk mendapatkan data yang benar-benar valid dalam penelitian ini berupa observasi, wawancara dan studi dokumentasi. Setelah dilakukan pengumpulan data, kemudian dilakukan analisis data. Analisis data dilakukan mulai dari proses pengumpulan data hingga proses pelaporan. Analisis data difokuskan pada latar alamiah madrasah, manajemen pendidikan karakter, faktor penghambat dan penunjang serta hasil yang dicapai dari manajemen pendidikan karakter di MI Miftahul Huda.

\section{HASIL DAN PEMBAHASAN}

\section{Latar Alamiah MI Miftahul Huda}

Madrasah Ibtidaiyah Miftahul Huda atau sering disebut MIMHa adalah merupakan bagian dari lembaga yang berada di bawah Yayasan Fathul Huda yang berdiri sejak tahun 1988 dan mendapat SK Depag pada tahun 1990. Sekolah yang diawali dari semangat pengajian ini pada tahun awal berdirinya hanya berjumlah 8 orang siswa ini terus menerus mengalami perkembangan baik dari sisi organisasi, sarana prasarana, jumlah guru dan jumlah siswa yang sekarang mencapai 402 orang siswa.

Fungsi MIMHa yaitu memfokuskan pada pendidikan karakter tauhid yaitu ikhlas, adil, jujur, tanggung jawab dan santun, Memberikan dasar kemampuan membaca, menulis dan berhitung, Memberikan pengenalan ilmu pengetahuan dan teknologi, Melatih dan merangsang kepekaan den mengapresiasi keindahan, Menumbuhkan minat pada olah, Mengembangkan kesiapan fisik dan mental untuk melanjutkan ke tingkat SMP/MTs. 
Tujuan MIMHa yaitu beriman dan bertakwa kepada tuhan yang maha esa, berakhlak mulia, dan berkepribadan khusus, Membuat peserta didik berilmu, cakap, kritis, kreatif dan inovatif, Melatih kemandirian, dan melatih kepercayaan diri, Melatih toleransi, kepekaan sosial siswa dan melatih demokrasi serta tanggung jawabnya.

\section{Perencanaan Pendidikan Karakter di MI Miftahul Huda}

Perencanaan pendidikan karakter sesuai dengan visi dan misi Madrasah. Visi Madrasah Ibtidaiyah Miftahul Huda "Menjadi Madrasah Yang Menghasilkan Lulusan Cerdas dan Berkarakter Tauhid", Sedangkan Misi Madrasah Ibtidaiyah Miftahul Huda "Menyelenggarakan Proses Pendidikan Yang Cerdas dan Berkarakter Tauhid", Untuk mewujudkan visi lulusan cerdas berkarakter tauhid, MIMHa menyelenggarakan lembaga pendidikan yang berdasarkan pada: (a) Prinsip asasi kelslaman (b) Pola asuh (c) Pengelolaan KBM dengan 4M (d) Nilai dasar karakter tauhid

Nilai-nilai karakter yang dikembangkan oleh Madrasah Ibtidaiyah Miftahul Huda adalah 5 nilai karakter tauhid yaitu: karakter tauhid ikhlas, karakter tauhid adil, karakter tauhid jujur, karakter tauhid tanggung jawab, dan karakter tauhid santun.

Penanaman nilai-nilai karakter pada kurikulum dan pembelajaran. Dalam kurikulum adanya jam pelajaran khusus penguatan karakter sekitar 30 menit sebelum mulai pembelajaran dan setiap pembelajaran selalu muncul kata-kata karakter tauhid. Penanaman nilai-nilai karakter pada pendidik dan tenaga kependidikan dilakukan setiap paginya ada briefing untuk motivasi kepada guru dalam melaksanakan tugas sebagai pengajar pembelajaran, adanya pengajian rutin tiap jumat pagi dengan cara mengundang ustadz dari luar. Penanaman nilai-nilai karakter melalui manajemen sarana dan prasarana pendidikan dilakukan dengan pengulangan kata-kata karakter tauhid, ketika di kelas, upacara, senam dan apapun kegiatannya selalu mengarah kepada penguatan karakter. Adanya gambar dan tagline karakter tauhid dan budaya malu. Penanaman nilai-nilai karakter melalui manajemen pembiayaan pendidikan adanya infak setiap hari jumat untuk diserehkan ke anak-anak yatim, ketika ada musibah termasuk gurunya juga melakukan infak.

\section{Pengorganisasian Pendidikan Karakter di MI Miftahul Huda}

Pengorganisasian dilakukan dengan adanya pembagian kerja di awal tahun pada saat rapat kerja adanya kontrak kerja, deskripsi kerja (job description) untuk kepala madrasah, wakamad madrasah, guru, tenaga administrasi yang rinci dan jelas apa saja yang akan dilakukan untuk satu tahun kedepan. Pembagian aktifitas menurut level kekuasaan dan tanggung jawab dilakukan sesuai alur seperti contoh kasus anak yang bertanggung jawab adalah guru, kemudian ke wali kelas sampai ke kepala madrasah baru ke yayasan. Untuk kasus yang sampai ke kepala madrasah biasanya kasus berat, seperti anaknya berkelahi biasanya anaknya sudah beres cepat sehari beres namun orang tuanya biasanya butuh waktu yang lama. Pembagian dan pengelompokan tugas menurut mekanisme koordinasi kegiatan individu dan kelompok. Seperti tugas asisten membantu administrasi sama jadwal ngajar, wali kelas mengkoordinir mata pelajaran, wakil kepala madrasah kurikulum berkaitan dengan administrasi dan membuat format yang berkaitan dengan 
administrasi kurikulum, formasi guru, kelas, komunikasi. Pengaturan hubungan kerja antar anggota organisasi dilakukan dengan musyawarah tiap level ada musyawarah di tingkat guru dan wali kelas, musyawarah kelas bawah yaitu kelas 1, kelas 2, dan kelas 3, Musyawarah kelas atas yaitu kelas 4, kelas 5 dan kelas 6. Musyawarah antara wakil kepala dan kepala madrasah, dan adanya musyawarah se-yayasan Fathul Huda Kota Bandung. Tahapan pengorganisasian pendidikan karakter:

Memerinci tugas-tugas yang harus dilaksanakan oleh guru dan staf untuk mencapai tujuan pendidikan karakter dilakukan diawal pembelajaran semester 1 diadakan rapat kerja selama seminggu untuk satu tahun kedepan dan di semster 2 diadakan rapat kerja untuk 6 bulan kedepan. Membagi seluruh tugas/beban kerja menjadi aktivitas atau kegiatan yang dilaksanakan oleh guru dan staf. Pembagian tugas guru dilakukan oleh kepala madrasah maksimal beban kerja 30 jam tatap muka dan minimal 24 jam tatap muka. Menyatukan atau mengelompokan tugas para guru dan staf, dengan cara yang rasional dan efisien; dilakukan dengan adanya kelompok kerja guru (KKG) untuk guru sains, guru matematika, guru PAl. Menetapkan mekanisme kerja untuk mengkoordinasi pekerjaan dalam satu kesatuan yang harmonis, dengan merumuskan standar oprasional (SOP) pendidikan karakter. Dilakukan dengan dibuatnya SOP untuk setiap kegiatan. Tata cara pembuatannya sudah disampaikan secara lisan namun untuk pelaksanaan pembuatan SOPnya sedang disusun, dan belum selesai.

\section{Pengarahan Pendidikan Karakter di MI Miftahul Huda}

Fungsi pengarahan dalam pendidikan karakter yaitu: mengadakan orientasi sebelum guru dan memulai melaksanakan tugas dalam hal mengimplementasikan pendidikan karakter dilakukan dengan rapat kerja dan pelatihan-pelatuhan. Mengikutsertakan guru, staf dan segenap warga sekolah dalam pembuatan perencanaan manajemen pendidikan karakter di sekolah sangat sulit dilakukan karena Yayasan sudah memiliki tim kurikulum yang menyusun perencanaan manajemen pendiidkan karakter di madrasah. Memberikan nasihat apabila guru atau staf mengalami kesulitan dalam melaksanakan tugas implementasi pendidikan karakter di maadrasah dilakukan ketika pada saat pengajian rutin, pada saat penguatan karakter oleh tim kurikulum Yayasan, dan pada saat breifing pagi hari untuk memotivasi guru yang akan melaksanakan pengajaran.

Peran kepemimpinan kepala madrasah sangat berperan dalam mengontrol guru-guru dan manajemennya sangat kuat sekali berbeda dengan kepala MTs yang fleksibel. Setiap guru harus mencapai target, tipe administrasi sangat kuat data-data harus masuk, targetan-targetan harus tercapai. Ada beberapa karakter yang baik yang bisa diteladani seperti dari segi tegas dan administrasi detail. Peran manajerial. Berkaitan dengan controling dan supervisi yang kuat satu semester sekali yang berkaitan dengan pelaksanaan pembelajaran dikelas, administrasi, dll. Peran kepala sekolah sebagai pengembang kurikulum dan pengajaran.

\section{Pengawasan Pendidikan Karakter di MI Miftahul Huda}


Proses pengendalian Penetapan standar dilakukan dengan cara adanya standar tertulis yang dimemiliki oleh tiap kelasnya, kelas 1 ada standarnya, kelas 2 ada sandarnya dst. Membandingkan performa pelaksanaan program dengan standar tersebut. Dilakukan dengan evaluasi setiap satu bulan. Kebanyakan masih belum mencapai target dari segi konsisten dan belum konsisten yang berkaitan dengan karakter seperti membersihkan kelas. Perbaikan terhadap kesalahan-kesalahan yang terjadi dilakukan evaluasi dengan cara dikurangi jika terlalu berat dan ditambahkan jika terlalu ringan setahun sekali dilakukan evaluasi.

\section{Faktor Penunjang dan Penghambat Pendidikan Karakter di MI Miftahul Huda}

Faktor penunjang pendidikan karakter (kekuatan): Potensi Fisik dan Fasilitas MIMHa, Fasilitas Internet Online, SDSQ, Potensi SDM (kompetensi guru), Pendampingan oleh Psikolog dan Terapis, MIMHa Learning Comunity Faktor penunjang pendidikan karakter (peluang): Peningkatan mutu akademik, Pengembangan Pendidikan Karakter, Pengembangan sekolah Inklusif, Penguatan kompetensi tahfidz, Pengembangan e-learning.

Faktor penghambat pendidikan karakter (kelemahan): Sisi manajemen pengelolaan, Sisi pengalaman pendidik, Akses Jalan, Sisi kematangan konsep. Faktor penghambat pendidikan karakter (tantangan): Standar mutu pengelolaan sekolah, Cara pandang masyarakat terhadap pendidikan secara umum, Peningkatan kesejahteraan pendidik, MIMHa sebagai Pusat Pembelajaran bagi anak, guru, orang tua dan masyarakat sekitar.

\section{Hasil dari Manajemen Pendidikan Karakter di MI Miftahul Huda}

Kriteria keberhasilan pendidikan karakter mengenai lulusan ada beberapa karakter yang terbilang sukses seperti karakter jujur dengan cara tidak nyontek dan tidak diberi jawaban saat Ujian Nasional meskipun hasinya kecil. Banyak juga lulusan yang melanjutkan ke pesantren karena di madrasah agamanya diajarkan sangat kuat. Secara umum sesuai dengan peserta didik. Dari laporan yang ada ternyata dalam segi kepemimpinan misalnya ada yang menjadi ketua osis di SMP dan SMA dari sisi penerimaan dengan temannya baik karena memiliki lingkungan yang baik dengan basic agamanya yang kuat, dalam kemasyarakat ada itikaf di masjid sebelumnya ada outbond building chararakter naumun sudah dihilangkan. Dan dari segi negatif hanya sebatas berisik karena dekat dengan kompleks perumahan. Ada peningkatan mutu pendidikan dari laporan orang tua mengenai shalat dan baca alqurannya baik. Adanya peningkatan efisiensi dan efektivitas pengelolaan dan penggunaan sumber-sumber belajar pendidikan karakter, melalui pembagian tanggung jawab yang jelas, transparan, dan demokratis. Ada peningkatan efektif dan efisiensi dalam pengelolaan sumber belajar untuk pendidikan karakter dengan cara mengambil sumber belajar dari alam mulai dari tanah, tanaman, hewan dsbnya. Respon masyarakat positif karena ada ahli masjid, sholat, suka baca alquran. Dari segi aman belum optimal karena anak-anak bermain di dalam gedung, dari segi nyaman sudah optimal mulai dari penyediaan fasilitas, sarana dll. Dari segi tertib sudah optimal anak-anak 
Efektif proses dan produk dilakukan dengan cara dibuatnya jam, informasi jelas ada dokumen dibagikan kepada setaip kelas, ada targetan yang ingin dicapai, ada tim kurikulum dalam pendidikan karakter. Produk program pendidikan karakter dibuat oleh tim kurikulum pendidikan karakter dan harus ada kaitan antara kegiatan dengan indikator penguatan pendidikan karakter. Efisien proses dan produk. Supaya efisien dalam pendidikan karakter yang targetannya besar, maka diterapkan pada semua kegiatan pembelajaran yang ada, semua warga madrasah terlibat dalam pendidikan karakter dan akhirnya lebih efisien dan tercapai. Produk karakter yang dibuat membuat anak lebih menikmati karena tidak terlalu banyak nilai-nilai karakter yang diterapkan dan tersebar dalam semua kegiatan pembelajaran.

\section{SIMPULAN}

Berdasarkan hasil penelitian, pengolahan, dan analisis data, maka dapat disimpulkan bahwa Manajemen Pendidikan Karakter dapat dijadikan salah satu program dalam rangka membentuk kepribadian siswa yang baik, agar nantinya dapat digunakan sebagai bekal hidup dimasa depan. Ketercapaian dan keberhasilan Manajemen pendidikan karakter salah satunya dipengaruh oleh manajemen yang baik yang terdiri dari proses perencanaan, pengorganisasian, pengarahan, dan pengawasan. Selain itu perlu diperhatikan pula mengenai faktor-faktor yang dapat mendukung dan menghambat ketercapaian dan keberhasilan Manajemen Pendidikan karakter.

\section{REFERENSI}

Badrudin, (2013). Dasar-Dasar Manajemen, Cetakan kesatu, ALFABETA, Bandung.

Mulyasa, E. (2013). Manajemen pendidikan karakter, Jakarta: Bumi Aksara.

Lickona, T. (2013). Educating for karakter: mendidik untuk membentuk karakter, Jakarta: Bumi Aksara.

Samani, M. \& Hariyanto, (2012). Pendidikan Karakter, Bandung: Remaja Rosdakarya

Undang-Undang Sistem Pendidikan Nasional No. 20 tahun 2003 tentang Sistem Pendidikan Nasional (Sisdiknas).

Wibowo, A. (2013). Manajemen Pendidikan Karakter di Sekolah, Yogyakarta: Pustaka Pelajar. 